\title{
MULHERES NO CÁRCERE E EDUCAÇÃO DE ADULTOS
}

\author{
MUJERES EN LA CÁRCEL Y EDUCACIÓN DE ADULTOS
}

WOMEN IN CARCERE AND ADULT EDUCATION

\author{
Maria Cristina SILVA ${ }^{1}$ \\ Carmem Lucia EITERER ${ }^{2}$
}

RESUMO: O presente artigo constituiu parte de nosso estudo realizado no doutorado. Dividimos esse texto em três momentos, sendo: o primeiro uma breve contextualização sobre os presídios femininos e as mulheres no cárcere, em um segundo momento apresentamos pequenas histórias de cinco mulheres que vivem no cárcere, em que procuramos trazer o cotidiano vivido por elas no presídio, e em um terceiro ponto tratamos da relação dessas detentas com a escola e os processos de escolarização das mesmas. Ao final traçamos algumas considerações e questões finais sobre as mulheres no cárcere.

PALAVRAS-CHAVE: Mulheres. Educação Prisional. Invisibilidade. Vivencias cotidianas.

RESUMEN: Este artículo fue parte de nuestro estudio de doctorado. Hemos dividido el texto en tres fases sucesivas: la primera una breve contextualización de las cárceles y las mujeres femeninas de prisión en un segundo tiempo presentes cuentos de cinco mujeres que viven en la prisión en la que trato de llevar la vida diaria por ellos en la cárcel y un tercer punto del tracto de la relación de estos prisioneros con la escuela y lo mismo de los procesos de escolarización. Al final trazar algunas consideraciones y preguntas finales sobre la mujer en la cárcel.

PALABRAS CLAVE: Las mujeres. Educación en las prisiones. Invisibilidad. Vivencias diarias.

ABSTRACT: This article is part of our study conducted in the doctorate. We have divided the text in three stages as follows: the first a brief contextualization on female prisons and women in jail, at second stage, I present short stories of five women living in the prison in which I try to bring their everyday lives lived in the prison and in the last step I tract of the relationship of these detainees with the school and the schooling processes. At the end I trace some considerations and final questions about women in prison.

KEYWORDS: Women. Prison Education. Invisibility. Daily life.

1 Docente UFMG - Universidade Federal de Minas Gerais. E-mail: bhcentro991@yahoo.com.br

${ }^{2}$ Docente Associada da Universidade Federal de Minas Gerais. E-mail: eiterercarmem@gmail.com 


\section{Os presídios e o aprisionamento de mulheres no Brasil}

A história dos presídios no Brasil data do início do século XVI, entretanto, as pesquisas não apontam elementos e registros de prisões específicas para as mulheres. Estudos sobre os presídios no Brasil indicam que somente em 1923 é que o jurista Lemos Britto foi o responsável pela elaboração de um projeto de reforma penitenciária brasileira, aconselhando, assim, o Ministro da Justiça a construir um espaço diferenciado para as mulheres. Longe de desejar conforto e tratamento digno para as detentas, ele visava afastar as mulheres do convívio, ou contato, com os homens, por julgá-las perniciosas.

A preocupação em empregar uma lógica de correção e de modelagem dos corpos de indivíduos infratores está presente em todos os momentos de nossa história, tendo em vista que a grande preocupação não é somente com aquelas que cometeram crimes, como assassinato, mas também com as prostitutas. Considerada crime, a prostituição deveria ser vigiada e punida.

Os estudos sobre as mulheres e sua atuação social no século XIX mostram que a maioria, ao ser detida, o era em virtude da prática de prostituição e vadiagem, já que, como já dissemos, tal comportamento era crime, de acordo com a legislação no período acima citado. Para além do trabalho, outro artifício recomendado era o religioso. A atividade de trabalho, conforme propõem os juristas, visava à correção por meio da ocupação laborativa e era fruto do desejo de que essas mulheres se afastassem definitivamente da vadiagem. No caso das mulheres no cárcere, é possível detectar também ao longo das discussões de Lemos Britto sobre a "natureza feminina" a perspectiva de ela ser moldada, modificada conforme influências externas. Apesar da distância temporal, o argumento de Lemos Britto ainda vige nos tempos atuais.

Aprofundando a discussão, no que tange a esta categoria específica, as mulheres encarceradas, no momento atual, têm sido motivo de debates e criação de novos programas. O governo brasileiro, ao propor uma articulação entre o Ministério da Justiça e Ministério da Educação, aponta na direção de traçar novas diretrizes e metas visando a população feminina. Dentre as iniciativas, a organização de um banco de dados sobre as mulheres no cárcere, o Infopen Mulher. O último relatório do Ministério da Justiça/Infopen (2014) aponta que o Brasil tem 673.731 pessoas em estabelecimentos prisionais e que $41 \%$ desta população não tem nenhuma condenação, ou seja, o processo pelo qual responde não foi transitado e julgado há mais de 90 dias. Aponta ainda que 
entre os 50 países que tem maiores taxas de encarceramento, o Brasil responde por um índice de aumento da população carcerária muito elevado. A cada 100 mil habitantes, 300 estão no cárcere, que segundo o mesmo relatório é o mais alto em todo o mundo. Entre os muitos desafios no que tange à população prisional, temos que apontar aqueles relativos às mulheres, uma vez que elas representam $7 \%$ do total.

O debate atual aposta em políticas prisionais voltadas para as mulheres, visando à sua reinserção. Nessas políticas, o trabalho e a escolarização têm grande centralidade. Novamente, a busca pelo reordenamento dos corpos femininos corrompidos pelo crime, através do trabalho e da escolarização, reapresenta o ideal do século XIX.

No ano de 2013, o Ministério da Justiça traz para a pauta das discussões sobre as mulheres em privação de liberdade a necessidade de ampliação de conhecimentos e estudos sobre as mulheres nos estabelecimentos prisionais. Nesta perspectiva, algumas pesquisas apontam discussões relevantes no que se refere à mulher no cárcere, a escolaridade das detentas e a questão da maternidade.

Alguns estudos nos deram apoio na discussão que promovemos; entre eles citamos aqueles sobre criminalidade no Brasil, como os de Canedo e Fonseca (2012), Beato (2012), em que apontam um enrijecimento de ações repressivas no combate e controle da criminalidade, pelos órgãos de segurança, que somados a outros fenômenos, como o aumento das taxas de desemprego, a repreensão ao tráfico de drogas, e a criminalização de pequenos usuários de drogas ilícitas, sendo estes de baixa renda, vem contribuindo para um aumento expressivo da população carcerária.

Outro trabalho importante é o da pesquisadora Silva (2011), que buscou compreender as razões que levariam as mulheres ao crime. Silva, em um artigo denominado Fios de tragédias: o feminino que mata, entrevistou mulheres que cometeram homicídios. A pesquisadora aponta para questões relevantes, para uma compreensão mais sutil sobre o universo feminino. Dentre as questões elucidadas em seu artigo, ela buscou compreender as histórias relatadas destas mulheres (ao entrevistálas), a dramaticidade da vida, da própria condição humana. Em uma perspectiva de análise histórica-filosófica nos assevera que:

[...] a tragicidade das mulheres presas aqui citadas é o ponto culminante do processo de marginalização e inferiorização dos seus lugares de mulheres, na verdade, até criam a individuação, mas de maneira anti-heroica. Essas mulheres são mortificadas no ato do crime e na convivência das prisões, suas identidades são imprensadas em conceitos jurídicos os quais as estereotipam como o signo do mal. $\mathrm{Na}$ 
Grécia antiga, os deuses, de alguma maneira salvavam os sujeitos de suas tragédias, porque afinal eles mesmos as provocavam, mas na nossa atualidade não há deuses criando tragédias, há sujeitos da fome, do tráfico, da miséria, do estupro que por maneiras diversas, praticam seus crimes. Os deuses as abandonaram às suas próprias sorte. (SILVA, 2011, p.14)

Outro relevante estudo é Mulheres Criminosas na Abordagem Interdisciplinar, das pesquisadoras CAMPOS; TRINDADE; COELHO (2008). Elas apontam dimensões múltiplas que atravessam o debate sobre mulheres e criminalidade, cujo tema também vem despertando interesse nos estudos sobre gênero. As autoras realizam um "estado da arte" das pesquisas sobre mulheres e crime. Uma síntese importante de como o crime envolvendo mulheres, sejam elas autoras ou vítimas, foram tratados pelos estudos e pesquisas.

Há que se considerar ainda, no momento atual, o imaginário que aponta o lugar ocupado pelas mulheres. Temos uma população feminina encarcerada, que se afasta de um ideal produzido socialmente e associado a um lugar pré-definido, o de cuidar e educar os filhos. Nestes modelos produzidos (o idealizado se revestindo de real e o real fora do padrão idealizado, mas na busca do ideal) soma-se uma racionalidade moral que coloca em discussão o lugar social ocupado por cada um.

Neste contexto social e político, as questões do crime e suas múltiplas relações nos impõem a busca por compreender questões específicas sobre as mulheres no cárcere e como podemos perceber sua (in)visibilidade no que tange às questões de gênero, classe, raça/etnia, entre outras que entrecruzam esta questão.

A percepção sobre as mulheres, regradas por estereótipos de gênero, de forma geral ainda está centralizada na figura idealizada daquela que gera, nutre e cuida. A realidade apresenta forte presença do papel de ser mãe, mas também mulher trabalhadora em seu ambiente doméstico e externo. É necessário apontar para a existência de uma população jovem, com baixa escolaridade, negras e pardas, num quadro de informalidade e/ou precarização nas relações de trabalho anterior à prisão e também no cárcere. É prevalente as relações familiares demarcadas por violência, álcool e drogas, uma constituição familiar bastante complexa, com forte presença da mulher na geração de renda, em uma maternidade desprotegida, moradoras em regiões periféricas das cidades, a presença da figura masculina nos relatos de envolvimento com o crime, enfim, dados que se chocam com estes estereótipos preconcebidos, idealizados. 
Sabe-se que mulheres comandam e participam de uma atividade de trabalho, o comércio de drogas, os contrabandos ilícitos de natureza diversa, assumindo um lugar que não conhecemos, pois não temos estudos ainda consistentes para compreendermos esse movimento.

Desnudar o cotidiano destas mulheres é como passar no detector de metal, enxergar para além do aparentemente visível. É preciso entender cada deslocamento dentro do presídio, bem como desfazer estereótipos sobre o crime e as mulheres, inverter as discussões sobre real e imaginário.

Para que melhor possamos compreender este complexo mundo prisional, passo a apresentar pequenas trajetórias de algumas mulheres, constituindo estas, parte de um universo maior, do Complexo Penitenciário Feminino Maria da Penha (CPFMP) ${ }^{3}$, que em 2013 contava com um total de 357 mulheres. Apresentaremos cinco pequenas histórias, sendo estas detentas da mesma penitenciária e alunas do curso de EJA existente no presídio.

\section{Mulheres (in)visíveis, suas histórias e seu cotidiano no cárcere.}

As histórias de cada aluna e as razões que as colocaram nesta condição de presas são bastante emblemáticas. Cada qual a seu modo, relatam seu envolvimento com o crime. Histórias atravessadas por violência, maternidade e convívio permanente com o tráfico. Cenas de um cotidiano de muitos brasileiros pobres e moradores das periferias de grandes centros.

Os nomes que vou utilizar são fictícios e foram escolhidos por mim, baseados em personalidades do cinema. Durante nossa pesquisa não foi possível discutir com as alunas que nomes escolheriam para os fins da pesquisa. A escolha das atrizes ligadas ao cinema foi uma saída encontrada pela pesquisadora para preservar a identidade destas mulheres, mas ao mesmo tempo a busca por expressar o cotidiano destas, uma metáfora sobre o vivido e experienciado de cada uma. Nem as atrizes, tampouco o cinema, e o que aqui conseguimos depreender, dariam conta de dizer tudo sobre as mulheres em privação de liberdade, mesmo que as histórias de alguns personagens se aproximem em muito da vida real.

\footnotetext{
${ }^{3}$ Nome fictício criado no cuidado de preservar a identidade da instituição, das detentas, professores e
} funcionários. 
Os nomes das personalidades do cinema aqui utilizados foram escolhidos tomando como princípio o filme, sua categoria, seu enredo, o drama, a ação e a personagem interpretada. Se a arte cinematográfica é uma ficção, a vida no presídio não o é, mesmo que a todo o tempo nosso desejo fosse que ela não passasse de uma cena vista em uma tela, uma ficção. O real aqui não são as personagens utilizadas para tentar contar sobre cada uma das detentas, mas seus relatos, seu cotidiano, sua dor, sua raiva, seu rancor, seu amor, sua sensibilidade, sua beleza. Sua continuidade/descontinuidade em seus percursos. As seis pequenas histórias foram construídas a partir de registros quando de nossa pesquisa de campo. Apesar das particularidades de cada mulher, no que tange a alguns aspectos, como a relação com o tráfico, maternidade, escolaridade, podemos estender e traduzir para o cotidiano de muitas outras que estão em privação de liberdade.

\section{Eva Mendes4- Cantar, dançar, ver filmes de ação é o que mais gosta.}

Eva Mendes tem, 31 anos, cor parda, tem 04 filhos $^{5}$, recebe visita de sua irmã e também tem autorização para uso de telefone público (telefone "orelhão" existente dentro da penitenciária, sob o monitoramento dos agentes), conforme escala organizada pela direção do presídio. Ela relata que foi injustiçada pelos irmãos que jogaram toda a culpa do crime sobre ela. Afirma que foi enganada e se envolveu no crime por não saber ler. Sempre faz referência aos filhos que não vê por mais de um ano. Seu companheiro já lhe agrediu fisicamente várias vezes e seus irmãos e seu filho mais velho já quiseram matá-lo. Para Eva Mendes, o marido é o causador de sua prisão e afirma que isto não dá para perdoar. Bem-humorada, tem dificuldades para compreender as explicações da professora no que se refere às atividades escolares. Quase nunca consegue realizá-las como solicitado, demonstrando assim sua dificuldade com a leitura e escrita, e provoca na professora desânimo e por vezes impaciência por não alcançar o objetivo com a atividade. Para Eva Mendes, um dia de escola é um dia a menos na cadeia. Esta sua certeza demonstra que tem conhecimento sobre a legislação e o papel da escola, ou seja, a frequência a esta como um direito a ser exercido no processo de remissão de pena.

${ }^{4}$ Eva Mendes - Atriz norte-americana de origem cubana. Atuou no filme Mais Velozes $\boldsymbol{e}$ Furiosos (2003).

${ }^{5}$ Segundo o que relatou a aluna "Eva Mendes", seus filhos (todos menores de 18 anos) ficavam com parentes, mãe e irmã.

RIAEE - Revista Ibero-Americana de Estudos em Educação, v. 12, n. 2, p.793-814, 2017. 
Sempre faz referência a Jesus e repete que pelo poder 'Dele' vai sair da cadeia. Afirmação aparentemente contraditória, pois ao mesmo tempo em que tem clareza de seus direitos, como o citado anteriormente sobre a remissão de pena, por vezes delega à religião poder para salvá-la.

Sua história com a escola e seus possíveis efeitos advindos da mesma é bastante emblemática em dois aspectos: primeiramente pela sua insistência e esforço em estar sempre às aulas, o que denota em nossa percepção vontade de aprender, socializar e ampliar seu mundo, bem como diminuir seu tempo na prisão. O segundo elemento, e que muito nos chamou a atenção, é a sua enorme vontade, disposição, sempre com muito entusiasmo, em participar de todos os eventos culturais, principalmente aqueles relacionados à música, dança e filmes. Eva Mendes adora música, dançar e assistir a filmes de ação. Sabe várias músicas e expressa uma fisionomia de felicidade (risos) nos eventos que tem música e dança. Quando em sala de aula a professora pergunta sobre as atividades coletivas proporcionadas pelo coletivo de professores (palestras, festas, atividades esportivas, filmes), na perspectiva de saber como elas vivenciaram, perceberam e aproveitaram a atividade; Eva Mendes relata de forma clara, entusiasmada, para a professora e colegas. Principalmente quando o conteúdo da atividade são filmes.

Os filmes, em especial aqueles que ela denomina como de ação, desperta nela não somente interesse, como também se converte em um artefato que sempre busca como recurso para seu lazer e diversão. Ao ouvir e perceber como Eva Mendes fala de sua vida antes do crime foi possível depreender, a partir de nossas observações, que os filmes, assim como a música, faziam parte do seu cotidiano antes de sua prisão e que no presídio estes são importantes para ela. É nítido seu gosto pelo cinema de ação, pelas músicas que falam de paixão, de amores perdidos e traições, como as do cantor Alexandre Pires. Quando pergunto o porquê de sua preferência, seu gosto musical, Eva Mendes afirma que a música fala sobre sentimentos, alegria, faz esquecer coisas tristes. Mas não somente os filmes e a música despertam em Eva Mendes entusiasmos, também dançar e cantar.

O seu cotidiano na penitenciária é entrecortado por muitas atividades em que a mesma busca participar, como o grupo de canto coral coordenado pela Igreja Batista, as reflexões proporcionadas nas atividades religiosas que demandam leituras e posteriormente responder a questões propostas nos folhetos. No que demanda de leitura e escrita, Eva solicita ajuda das colegas para sua realização e busca memorizar o que 
respondeu. A sua estratégia de memorização sempre é utilizada como recurso para lidar com as questões da leitura e escrita.

Nas atividades de julho, ela participou da 'festa julhina', dançou quadrilha, atividade organizada pelo professor de arte. As participantes precisavam não somente dançar, mas também representar cenas cotidianas da infância à fase adulta, entendendo a sequência e comandos do professor. Durante os ensaios, Eva Mendes deixava de fazer as atividades em sala de aula, o que para a professora não era um problema. Os ensaios ocorriam no pátio e era possível acompanhar como eles ocorriam. Eva Mendes sempre estava nos ensaios e era possível perceber que sua atenção ficava sempre voltada para aprender como as demais faziam. Observar o jeito e a forma, os modos como ocorria a atividade, naquela situação ali envolvida, o ensaio para a festa 'julhina', denotava ser mais fácil para sua compreensão. Em contrapartida, em sala de aula a professora sempre repetia por mais de uma vez as informações sobre o que e como deveriam ser desenvolvidas as atividades e era possível perceber como Eva Mendes tinha dificuldade em compreender o que era informado pela professora.

Para os que trabalham na escola com Eva Mendes ela denota ter um déficit intelectual, o que justificaria sua enorme dificuldade em compreender o ler e escrever. As atividades que demandam repetição com base em um modelo, assim como decorar letras de música e aprender a dançar, em que se repete várias vezes o mesmo gesto, são atividades que ela não apresenta dificuldades em sua realização.

Eva Mendes participa de outras atividades dentro do presidio, como a "capina", ou seja, limpeza e retirada do mato nos espaços internos do complexo penitenciário. Ela sempre se queixava de não ser incluída nas atividades de trabalho remunerado. Não foi possível saber as razões disso, mas segundo a professora e outras colegas de sua turma algumas das empresas que atuam dentro da penitenciária conhecem Eva Mendes e sabem que ela demonstra dificuldades em realizar atividades que não aquelas que demandam somente força física, como na fábrica de blocos ${ }^{6}$.

As atividades de trabalho ofertadas por empresas externas nem sempre são compatíveis com as habilidades das detentas e em número suficiente para todas elas, caso toda a população de mulheres do complexo demandasse trabalho. As mulheres, ao serem recebidas no Complexo Penitenciário, passam por várias entrevistas em que

${ }^{6}$ A fábrica de bloco de cimento destinado a construção civil é uma das atividades de trabalho ofertada dentro da penitenciária. É uma parceria entre uma empresa e a Secretaria de Administração Prisional do Estado. 
devem manifestar o seu desejo em trabalhar e estudar. A manifestação durante a fase de avaliação fica registrada em sua ficha individual. O serviço social ajuda na orientação do trabalho e na escola, mas outros critérios também são considerados, como comportamento, disciplina, tipo de crime e regime, antecedentes, idade e escolaridade.

A empresa pode ou não aceitar a detenta para trabalhar, e a avaliação desta perpassa por critérios como capacidade para realizar a atividade, comportamento, disciplina, responsabilidade da mesma durante e fora do horário em que se encontra trabalhando na empresa. As vagas, principalmente aquelas remuneradas adequadas a cada detenta, existem em número reduzido, o que faz com que ocorra uma inexistência de trabalho remunerado para todas que possam usufruir desse direito. Assim sendo, nem todas podem trabalhar para remissão de sua pena e tampouco ganhar dinheiro, programar sua vida após o cárcere ou mesmo adquirir produtos de higiene pessoal.

É importante destacar na história de Eva Mendes como ela se relaciona com a escola como um lugar importante para sua vida, no entanto, em uma perspectiva mais cultural em que a música, a dança e todas as atividades culturais são valorizadas e reconhecidas por ela. Também é importante reconhecer que Eva Mendes valoriza a escola, a sala de aula e a professora, pois faz de forma clara a associação entre ser a escola o lugar que promove esses eventos, bem como de que também precisa usufruir de seu direito de remissão de pena, mesmo que o processo de alfabetização não constitua grandes avanços no que tange ao domínio do código escrito. Ela reconhece a escola como espaço de socialização, como local para exercer seu direito, não só referente ao estudo, mas também para remissão de pena. A escola tem um sentido, buscar alegria; um objetivo, diminuir seu tempo no presídio; uma representação simbólica, sair da cela. Assim ela a concebe.

\section{Norma Aleandro7 ${ }^{7}$ Gosta de fazer comida para os filhos, andar na rua, ir ao supermercado.}

Norma Aleandro tem 41 anos. Conta que casou muito jovem e que o marido era mais velho. Morava na zona rural, em uma fazenda onde tivera dois filhos. O relacionamento não deu certo, pois o companheiro fazia uso de bebida alcoólica em excesso, o que para Norma foi a principal razão dos vários desentendimentos do casal e,

${ }^{7}$ Norma Aleandro. Atriz, roteirista e diretora de teatro e cinema na Argentina. Foi protagonista do filme La Historia Oficial (1985), vencedor do Óscar de melhor filme estrangeiro em 1986. 
por fim, da separação. No interior onde viveu sua infância e início da juventude, ela frequentou escola, mas afirma não ter conseguido aprender a ler e escrever. Após essa fase de sua vida, ela veio morar em um grande centro urbano da região sudeste, onde conheceu seu atual companheiro e teve outros filhos. Mesmo sem o domínio da leitura e escrita, Norma relata que começou a trabalhar como autônoma e em seu trabalho sabia como dar troco, e fazer compras no supermercado. Nas conversas informais, ela relata que quando ia ao supermercado fazer compras identificava os produtos pelos rótulos e conseguia também calcular se o dinheiro era suficiente para suas compras. Uma das estratégias utilizadas era ficar olhando na tela do computador do caixa quando ia passar os produtos que havia escolhido e observar o valor que aparecia na tela comparando-o com o dinheiro que possuía em mãos.

Norma tem uma condenação que envolve venda de drogas, o que levanta suspeitas para alguns de que ela forja sua condição de não domínio do ler e escrever. Tal suspeita não se confirmou durante nossa pesquisa e talvez ela tenha ocorrido pelo fato de que as mesmas estratégias utilizadas nas compras ao ir ao supermercado também fossem utilizadas no comércio de vendas de drogas. A sua irmã é que vai às visitas e é quem leva produtos de higiene, biscoito, etc., para ela. Tem um filho pequeno de 1 ano e 6 meses que está com a sogra. Os filhos, um de 16 anos, e uma menina de 4 anos, ficam com a irmã. Os outros com mais de 18 anos tem vida própria, sendo que um deles, durante nossa pesquisa, fora assassinado por razões não claras, segundo a própria Norma. ${ }^{8}$

Sempre atenta a tudo que acontece na turma, sabe muito sobre direito e o funcionamento da cadeia, tem um advogado constituído por conta de seus familiares, que acompanha seu processo. Trabalha em uma fábrica de embalagens de refratários que funciona dentro do presídio.

A história de Norma aponta para questões importantes, pois mesmo não tendo domínio pleno do código escrito sabe fazer uso de dinheiro. Aprendeu devido a seu trabalho anterior à sua prisão, comércio de alimentos, e como dona de casa, ao fazer compras no supermercado, como já o dissemos. Em algumas atividades em sala de aula, ao escolher o produto, ela sempre falava sua marca e afirmava que o produto escolhido

\footnotetext{
${ }^{8}$ Durante nossa pesquisa vivenciamos o sofrimento e dor de Norma pelo assassinato do filho. Segundo ela, seu filho era casado e trabalhava. Relata que veio a saber que junto aos pertences do filho estava a marmita que colocava a comida para levar para o trabalho. Para Norma, seu filho foi vítima de intriga e quem o matou tinha como alvo outra pessoa. Por vários dias Norma chorou silenciosa, queixou de muita angústia e dor no peito e saudade do filho e quase não participou das atividades.
} 
era o que ela sempre comprava quando ia ao supermercado. Sempre faz muita associação em sala de aula entre sua vida antes da prisão e o que gostava de forma muito saudosa. Conta os dias e horas para estar novamente em liberdade. As lembranças anteriores ao cárcere, ao fazer menção aos filhos, familiares, companheiro, atividade de trabalho, mobilizam-na para uma busca constante de orientar sua vida no presídio para projetos futuros. Relata que o dinheiro depositado em conta bancária, advindo do trabalho que vem executando dentro do CPFMP, vai auxiliá-la a retomar sua vida, abrir seu próprio negócio, cuidar dos filhos. Realiza conversas por telefone público autorizadas pela direção da penitenciária e afirma que eles são de grande importância, pois assim tem notícias dos filhos. "Escreve" cartas para seu companheiro, que também está no cárcere, com a ajuda de uma colega de alojamento. Ela a dita para que a colega as escreva.

A questão do trabalho no presídio para Norma é algo que nos remete a um valor maior, seja para sustentar um lugar de mulher independente, seja para ela ocupar os dias de dor e sofrimento, como a saudade dos filhos (principalmente dos mais novos), bem como buscar sua remissão de pena. Norma sempre relata para a professora que está com muita saudade dos filhos e que reza e trabalha para os dias se tornarem menores.

Duas histórias contadas por ela nos revelaram ser bastante ricas no que tange à sua relação com seu processo de escolarização. A primeira delas foi quando a empresa onde trabalha no presídio levou todas as detentas para realizar cadastro bancário e assim abrir conta no banco. Norma diz ter se sentido muito constrangida por não saber assinar. Deixar a digital na folha foi para ela motivo de muita vergonha, assim como usar roupa de presidiária. Ao relatar para a professora a situação vivida, a professora utilizou este momento para registrar e reafirmar junto às demais alunas que a escola é importante para a vida delas e que assim devem se empenhar mais nas atividades escolares. As observações da professora sobre o valor da escola e do domínio da escrita e leitura apontam para a questão de que frequentar a escola não devesse ser somente um desejo em função de remissão da pena. O relato de Norma é utilizado para afirmar um valor social que possui a escrita. A professora pergunta para Norma porque ela não assinou se ela o fazia todos os dias durante as aulas e qual a razão do uso de sua digital para a assinatura. A resposta foi de que ela não tinha naquele momento os documentos ${ }^{9} \mathrm{e}$

\footnotetext{
9 Os documentos dos encarcerados que se encontram em regime fechado permanecem em poder do
} Estado enquanto estiverem em cumprimento de sua sentença. 
assim o sendo não era possível realizar a assinatura para a abertura de sua conta bancária.

Norma teve vergonha diante do gerente da agência bancária ao colocar sua digital. Ela, mesmo que ainda sem total domínio da escrita, possui documentos e sabe assinar o nome, pois sempre na lista de presença assina-o. Por que nesta situação de abertura de conta ela ficou tão constrangida em deixar sua digital? Por fim, outra questão que nos surge frente a esta situação relatada por Norma foi que a roupa, as algemas, o aparato de segurança, deixaram-na constrangida. O uniforme é para boa parte das detentas símbolo negativo de confirmação de sua condição. A cor vermelha tem neste espaço prisional uma conotação de marca, carimbo ou rótulo. A escrita SUAPI ${ }^{10}$ definindo o pertencer ao sistema prisional soma-se à cor, provocando a aversão de muitas pelo uniforme. Ela diz que foi a roupa, o aparato policial, os olhares, o que pesou naquele momento. Apagada sua condição de mulher anterior ao cárcere, em que era independente, em que saía para fazer compras no supermercado, cuidar dos filhos e da casa, ela ficou fragilizada, diminuída frente ao gerente da agência bancária. Perda de poder, mas não de sua consciência de desconforto e de exposição ao outro. Essa sua experiência fez com que sonhasse em sair do presídio, retomar a vida com a venda de sanduíches.

O gosto pela culinária alimenta também sua perspectiva de ter de volta seu trabalho. Como outras mulheres, ela também relata ter sonhos de deixar a vida do crime, voltar para casa, encontrar os filhos e trabalhar. Sempre afirma que conta os dias para sair e que Jesus vai lhe dar força para suportar tudo. Acredita que sem a ajuda de uma "divindade" superior e que a fortaleça não é possível. Suas afirmativas apontam que ela tem pouca expectativa nas leis terrenas. Norma relata que outras pessoas de sua família também estão presas, como sua cunhada e seu atual companheiro. A sua história também nos revela que a violência perpassa sua juventude, assim como a inexistência de escola e orientação familiar quando ainda bem jovem.

O desejo de ter outra vida que não fosse de mulher submissa ao primeiro companheiro, de não sofrer violência por parte dele, teria a levado a um percurso diferente do que idealizou ao mudar para uma cidade grande. Nessa nova vida, já em um grande centro urbano, nos parece que ela enveredou por um sonho de sucesso financeiro e consumo, mas buscando, enquanto mulher, além da independência financeira, um novo amor. Norma fala com muito carinho de seus filhos e de seu

${ }^{10}$ SUAPI - Subsecretaria de Administração Prisional. 
segundo companheiro. Mostrou-nos foto dos filhos e do marido de quem fala com muito cuidado. Pergunta para a professora, mas em um tom de afirmação: "ele não é bonito?", ao apontar a foto do companheiro. Apresenta para a professora foto dos filhos pequenos e na sequência, outra afirmação: “eu amo meus filhos”. Demonstração clara naquele momento de que a família, os filhos, sua casa e o trabalho e também a escola representam um lugar de afirmação, de busca, de experiências vividas e de consciência de uma condição a qual sonha: estar do lado de fora. Comer coxinha, mascar chiclete, fazer almoço para os filhos, andar na rua, ir ao supermercado. Sonhos banais e cotidianos, simples, mas fundamentais e enormemente desejados por esta mulher.

\section{Sofia Vergara ${ }^{11}$ - Conhece bem o mundo e o cotidiano na periferia.}

Sofia Vergara tem 33 anos, se auto define morena, mãe de duas filhas. Segundo ela, já esteve anteriormente presa pois, afirma, "vacilou". Quando de nossa pesquisa, Sofia trabalhava em uma empresa dentro da penitenciária, mas após brigar em um final de semana foi afastada do trabalho. Permaneceu no castigo por dez dias, sendo impedida de participar das atividades escolares. Durante o período de isolamento foi autorizado o envio das atividades escolares para ela. Após o retorno à sala de aula, disse para a professora que não lhe foi permitido seu retorno ao trabalho. Sofia é a aluna mais ligada de forma afetiva à professora e em dias de sua ausência ela não gosta de ficar na sala. Senta próxima à mesa da professora, arruma o armário, auxilia-a em todas as atividades. Muito cuidadosa com sua pasta e cadernos, gosta de colorir e sempre pede papel colorido para fazer desenhos e mandar para suas filhas. Denota ser a aluna que consegue ler e escrever e realizar as atividades com melhor desempenho. Folheia revistas, livros, busca ler pequenos textos. Sempre fala de seu time (o "galo") e de seus ídolos: Neymar, jogador de futebol, e o ator Cauã Reymond. No caderno tem pôsteres de ambos, colados. Consulta o calendário que tem na sala e conta os meses, calcula quando vai sair de "descida" 12 e quanto tempo ainda falta.

Segundo Sofia, seu companheiro foi condenado e também está preso. Afirma que não promete nada quando sair livre, pois não sabe o que espera por ela fora do presídio.

${ }^{11}$ Sofia Vergara - Apresentadora, atriz e modelo colombiana.

12 Palavra usada pelas detentas para designar o benefício de ficar uma semana junto de seus familiares. Essa permissão é concedida pelo juiz da Vara de Execução Penal mediante avaliação do processo da detenta. 
Tem muitas dúvidas sobre sua vida após o cárcere. Sofia alimenta ou tece poucos sonhos após o cumprimento de sua pena ou avalia de forma racional sua própria condição de existência. Em meio ao mundo de consumo permeado pelo tráfico e à sua segunda experiência de ficar presa, avalia o quanto será difícil ter emprego e dinheiro para sustentar as filhas. Conhece bem o mundo e o cotidiano na periferia. A realidade dura no presídio e sua dificuldade de se calar frente aos fatos que vive, fora, assim como lá dentro, como a violação aos direitos das detentas, traz para si uma avaliação menos otimista, não menos realista, de como é o mundo fora dos muros e das grades. Sofia é a mais emblemática das alunas da turma de alfabetização. Recebe as atividades escolares propostas pela professora e as realiza sem dúvidas ou embaraços. Pelas avaliações realizadas em sala de aula, ela já poderia ter avançado em sua fase de escolarização, o que demanda mudança de professora e sala. Mas Sofia não aceita a mudança de professora tampouco gosta de discutir este assunto. Após ter seu envolvimento em briga com outra interna, ter ficado afastada das atividades escolares e perder sua vaga de trabalho, ela começou a apresentar comportamento desinteressado pelas atividades escolares. Ao perguntarmos à professora como se define as sanções, ela só disse que o que Sofia fez foi grave, mas que o castigo aplicado fez com que a aluna deixasse de se interessar pela escola. Assim, Sofia apresentou-se por vezes alegre, noutras abatida ou desmotivada. Na festa 'julhina', ela estava presente, e quando identificou a pesquisadora, acenou com a mão e sorriu. Estava alegre, cantou e dançou durante o show.

Sua relação com as demais internas é sempre ambígua, cuidadosa e defensora dos direitos de todas, mas ela mesma se diz do "pavio curto". Explosiva, não gosta de ser vigiada e tampouco daquelas que fazem comentários sobre sua vida. Atenta a todos e a tudo, principalmente sobre seus direitos, ela não esconde seus saberes. Sempre conversa e conta as histórias cotidianas do presídio, o dia-a-dia, as fofocas, as que chegam e as que vão embora. A cada dia do mês faz um " $\mathrm{X}$ " no calendário e faz cálculos matemáticos do tempo que ainda resta para o fim do ano, do tempo que lhe resta para poder sair, estar de "decida". Em nossas conversas, pergunto para Sofia quanto tempo ainda falta para cumprir sua pena e ela afirma que em 2016 vai estar de "descida". Tento amenizar o longo tempo, que ali parece não passar, argumentando a ela que não está distante e que vai conseguir. Sofia faz uma referência religiosa e afirma que na "cadeia, na tranca" o tempo não passa. Sem o trabalho e com todos de olho sobre ela, seu tempo está mais lento do que o nosso tempo real, sua vida mais vazia de sentido e 
significados, sua angústia aumentada. Sofia ultimamente tem ficado menos feliz, falado pouco em Neymar, seu ídolo, comentado pouco sobre as novelas, entusiasmado-se menos com seu time de futebol.

\section{Lupita Nyong' ${ }^{13}$. Ninguém sabe o que acontece em nossas vidas.}

Lupita Nyong'o tem 50 anos, 2 filhos, está no regime semiaberto (albergue). Quer muito ir para sua casa, na região do Vale do Aço, reencontrar com seu atual companheiro. Em nossas conversas informais ela diz já ter cumprido sua pena, mas como não tem advogado, o juiz ainda não a ouviu. Em sua cidade trabalhava como diarista e faxineira e segundo diz era sempre muito solicitada por várias famílias. Após romper com seu primeiro companheiro, envolveu-se com bebidas e se viu diante de muitas complicações. Ao longo da vida encontrou um novo companheiro, e quando de sua prisão eles já viviam juntos e ganhavam dinheiro com a coleta de materiais recicláveis.

A história de Lupita nos parece demonstrar o descaso da justiça, bem como a ausência e a solidão de muitas mulheres. É negra, por vezes muito risonha e sempre falando em Deus. Lupita, que sempre é muito educada e atenciosa, tem um filho que está preso e que segundo ela, matou todos os seus inimigos, não sobrando nenhum. Argumenta: "ninguém sabe o que acontece em nossas vidas". Relatou na sala de aula histórias de violência na família, como estupro e agressões em seus relacionamentos amorosos. Sempre está alegre, risonha, faz graça com tudo, até mesmo com sua condição de mulher e negra. Lupita contou que certa vez uma senhora disse que ela era a Chita (a macaca personagem do filme "Tarzan, o rei das selvas") e que para macaco, a ela só faltava orelhas. Lupita disse que respondeu à senhora que tinha orelhas e de imediato colocou as mãos nas orelhas. Lupita então responde para tal senhora que se eram as orelhas que estabelecia a diferença entre ela e o personagem chita, não havia então nenhuma diferença. Ela, Lupita, e a "macaca chita" de fato tinham semelhanças.

Contou da agressão como se tudo fosse natural em sua vida. Quando lhe pergunto se concordava com tal comparação, ela me responde em tom de indagação: não é

${ }^{13}$ Lupita Nyong'o é uma atriz mexicana de naturalidade queniana e é a primeira de seu país a ser indicada e a vencer um Oscar de melhor atriz coadjuvante, em 2014, no filme 12 anos de escravidão (2013). 
verdade que ela é negra e tem semelhanças como o personagem, a macaca chita? Lupita parece não ter dado a devida importância ao ser comparada a um animal e os efeitos pejorativos e racistas de tal comparação, acreditando ter sido somente uma provocação naquele momento de discussão. O racismo sofrido por Lupita foi relativizado, ignorado, como que algo comum em sua vida. Naturalizou sua condição de mulher negra e "aceitou", como que mais uma brincadeira. Em sua difícil trajetória de vida, permeada por violência, pobreza, álcool, o preconceito sofrido por ser negra parecia menor, diante da imensa vontade de estar em liberdade.

Lupita traz em sua história duas situações que muito chamam a atenção: a afirmação de não ter advogado (e por isso ainda estar presa) e a naturalização de sua condição racial e a cor da pele como motivação para ser comparada a animais (ao macaco). Sempre que se aproximava para conversar, ela falava a mesma história de que seu tempo de permanecer na cadeia já havia terminado. Relatava que o albergue (semiaberto) é um inferno, muita fofoca, brigas, intrigas.

Para nossa surpresa o que é nomeado de semiaberto (albergue), onde as detentas permanecem em um espaço de maior circulação, diferente dos alojamentos (celas), é relatado como um lugar que não é desejado por muitas devido a constantes brigas e intrigas, muitas tendo como pano de fundo relações amorosas correspondidas ou não. Não tivemos acesso a este local dentro do complexo penitenciário, mas pelo que relatou Lupita, nos remeteu a um espaço que proporciona maior liberdade às detentas e que essa condição proporciona fofocas e ciúmes entre as mesmas e produz muitas intrigas. O que fora vivenciado e relatado por Lupita sobre o semiaberto é reafirmado por alguns professores e muitas detentas, como um local permeado por muitas brigas.

Lupita tinha razão em muitas de suas queixas. Em julho de 2013 conseguiu ser ouvida pelo juiz e foi para sua casa. Em sua confusa e controversa história, representa talvez o que de mais perverso ocorre em nossa sociedade. A sua condição de mulher, negra, presa, sem domínio da leitura e escrita, e que não conhece a cidade em que se localiza o presídio em que se encontra, dificultando assim sua possível mobilidade. As várias interseções de sua vida e condição indicam a ausência do direito de ter um representante da justiça para lhe ouvir. Esses elementos podem ser percebidos na ausência de um advogado, a inexistência de visitas por não estar na cidade em que se encontram seus familiares e companheiro, a condição financeira, o desconhecimento de seus direitos enquanto mulher quando era agredida, a falta de reação frente aos desrespeitos vários de que foi vítima. 
Este desrespeito quanto a ser mulher, negra, presidiária, pobre, baixa escolaridade, nos parece também ter sido evidente no que se refere ao seu direito quanto a ter um advogado público. A pouca importância dada a suas queixas de estar presa após cumprimento de sua condenação nos chamou a atenção, mas sua voz não fazia eco para a grande maioria que com ela vivia. Sem familiares que lhe pudessem acolher e visitar, ficou à margem, aguardando que alguém ouvisse seu lamento. As pessoas que não se encontram presas, mas que convivem cotidianamente com aqueles em privação de liberdade, falam sempre que as histórias relatadas são invenções, mentiras. Perpassa no mundo prisional a lógica perversa de que não se deve dar voz aos presos e sempre desconfiar do que dizem. Para muitas como Lupita, não é fácil ser ouvida por alguém que não seja suas colegas de presídio. Até onde nossa pesquisa nos permitiu saber, Lupita foi auxiliada por uma colega que solicitou ao seu advogado, em uma visita, que certificasse se de fato já havia transcorrido o tempo de cumprimento de sua condenação e se de fato deveria estar em liberdade, o que se verificou.

A história de Lupita nos faz estabelecer aqui uma reflexão. Podemos inferir que sua história não é única nos presídios brasileiros, onde o abandono e o preconceito afastam cada vez mais estas mulheres de terem seus direitos resguardados, de serem respeitadas e ouvidas. Grande parte das detentas não possui advogado constituído por conta de seus familiares (ou conhecidos). Por depender do serviço público ofertado pelo Estado (defensor público), direito este garantido por nossa Constituição, mas com um percentual mínimo de profissionais atuando, se arrastam os processos de todos aqueles que precisam contar com estes serviços. Os que por iniciativa de familiares contratam advogado, muitos são explorados ou enganados, constituindo, por vezes, uma outra rede de dependência, que por vezes está associada à troca de favores nem sempre lícita. A ausência do Estado, no que tange à garantia do direito de um advogado, alimenta um mundo paralelo na constituição de advogados, em que estes são contratados por organizações envolvidas com o tráfico, que, por sua vez, garantem o direito não sustentado pelo Estado e constituem também a submissão e "dívida" com quem lhe concedeu esse direito. Ao sair ou ter algum benefício concedido, que pressupostamente deveria reiniciar sua trajetória ao convívio social, o apenado retoma sua vida em liberdade já associado a uma dívida que deve pagar. Uma liberdade concedida pelo ilícito, um círculo que se repete. Para sair da prisão, o detento precisa ter um advogado; ao tê-lo, este foi adquirido mediante uma troca de favor; que, por sua vez, pede em 
forma de pagamento outros favores, como o silêncio, a comercialização de produtos ilícitos, entre muitos outros.

Voltando à história de Lupita, ela consegue, após vários meses de tentativas, ser ouvida pelo juiz da Vara de Execução Penal. O juiz, ao verificar seu processo, certifica que ela já poderia estar em liberdade. Não conseguimos saber os desfechos desta história, mas fato é que em um tempo muito curto, menos de uma semana, seu lamento foi ouvido. Como? De que forma? Por que? Se não era ouvida antes? Talvez nunca venhamos a obter esta informação. Nossas hipóteses são muitas, entretanto são hipóteses. Lupita é uma "mulher livre", ao menos da cela, das grades, talvez quem saiba um dia da fome, da pobreza, do preconceito por ser negra, mulher, de baixa escolaridade, ex-presidiária.

\section{Leleti Khumalo ${ }^{14}$. Veio para o Brasil, mas não conhece o Brasil.}

Leleti Khumalo é de Cabo Verde, afirma que veio para o Brasil de forma ilegal com o sonho de ganhar dinheiro e realizar uma "cirurgia" para que pudesse engravidar. Tem menos de 30 anos de idade, negra, tem dificuldade em compreender o português falado no Brasil. Ao chegar ao Brasil, ela foi presa no aeroporto por transportar drogas. Leleti conta que em seu país trabalhava em um salão de beleza, tem mais irmãos e que brigava muito com sua mãe por causa de seu sonho de vir para o Brasil. Em seu país natal, ela deixou namorado e amigos, acreditando ser possível retornar rápido. Quando já na penitenciária, teve muita dificuldade para adaptar, talvez em função do não domínio da língua e desconhecimento das leis brasileiras. Está em regime fechado, não recebe visitas, trabalha em uma das empresas instaladas dentro do complexo penitenciário. É por meio da remuneração deste trabalho que compra produtos de higiene pessoal e outros objetos autorizados, como sandálias, frutas, biscoitos. Comunica-se muito pouco com seu companheiro e familiares e quando o faz é por meio do telefone público. Relata que estudou muito pouco em seu país e que deseja cumprir sua pena no Brasil. Leleti alimenta a ideia de que deve voltar para seu país "limpa", expressão utilizada quando é perguntada pela professora se tem previsão de saída. Afirma que tem vergonha de sua condição de presidiária e indica que no Brasil tem a

\footnotetext{
${ }^{14}$ Atriz sul africana, atuou no filme Yesterday (2004), dentre outros.
} 
possibilidade de receber um tratamento mais humanizado. $\mathrm{O}$ que nos faz nos perguntar sobre a realidade dos presídios em Cabo Verde.

A condição de presa estrangeira dificulta ou torna a vida de Leleti mais complexa do que das demais. As dificuldades em compreender hábitos e costumes de um outro país que não o seu, compreensão e domínio da norma culta mesmo que seu país de origem, de colonização portuguesa, utilize o português. É visível as dificuldades de domínio da cultura local, bem como da língua portuguesa na variante brasileira. Durante nosso período de pesquisa presenciamos em vários momentos choro e queixas de muita saudade por parte de Leleti. Na sala de aula, ela busca compreender as atividades, mas também é visível um choque cultural permeado por angústia e tristeza. Veio para o Brasil, mas não conhece o Brasil, só pela televisão, um lugar que a assusta pelo movimento de carros e pessoas. Se a trajetória de Leleti é difícil de entender para seus professores, não o é para nós, se partimos de uma perspectiva de exploração de mulheres jovens no que tange ao uso delas para o tráfico de drogas. A partir do que ela relata, sua família mora em uma zona periférica da cidade de Praia, capital de Cabo Verde $^{15}$. Ainda muito jovem, sofreu com as imposições culturais de seu país, onde a mulher está condicionada a um respeito ao pai e, após o casamento, ao marido. Segundo Leleti, não é permitido separação, traição por parte das mulheres, podendo elas serem devolvidas ao pai caso não correspondam ao esperado, ou seja, cumprir seu papel de mãe e esposa dedicada. As relações familiares em seu país nos indicam uma condição de submissão sobre o julgamento do masculino, que coloca as mulheres em um lugar de menor valor. Marcas deixadas por um processo de colonização portuguesa e expropriação do povo caboverdiano.

\section{Considerações finais}

Ao perpassarmos por uma pequena discussão sobre a constituição das regras e formas de controle da sociedade e os presídios enquanto instituições formais de punição e castigo a todos aqueles que se contrapõem às regras de um viver em sociedade, apontamos como essas instituições foram pensadas para as mulheres. No caso brasileiro, as instituições penitenciárias tiveram, além da influência dos juristas, uma forte

${ }^{15}$ O censo de 2012 de Cabo Verde informa que a capital Praia contava com 125 mil habitantes. 
conotação moral na perspectiva de combater a prostituição feminina e inibir a vadiagem, ambas percebidas como um mal a ser coibido. Mesmo que tal visão seja do Século XIX, podemos afirmar que permanece um imaginário sobre o feminino, delegando a estas o lugar doméstico, a maternidade, o cuidado com os filhos.

Tomamos como referência os registros de nossa pesquisa, os relatos das cinco mulheres aqui apresentados. São parte de um contexto muito amplo e complexo; a penitenciária quando de nossa pesquisa de campo tinha uma população de 357 mulheres, e foi possível certificar sobre este público que mais de $80 \%$, das encarceradas foram condenadas por motivos relacionados ao tráfico de drogas. Das alunas participantes da pesquisa, somente uma delas não está presa por ligações ao tráfico de drogas. A relação das pesquisadas com a escola e o trabalho perpassa caminhos diferentes, entretanto todas sabem as regras do jogo que circula dentro da penitenciária para acessar estes benefícios. Cabe por fim pontuar que não existe vagas de trabalho para todas e que tampouco os espaços para a realização das atividades escolares são suficientes para um número maior de estudantes. Cabe aqui apontar que desde 2011, quando de uma nova redação da Lei de Execução Penal (LEP 7.210/1984), a Lei n. 12.433/2011, o Brasil define a frequência à escola como forma de remissão da pena. Anterior a este período estava garantido somente as atividades de trabalho. A nova redação da LEP aponta estas atividades como direito do encarcerado, mas não garante a possibilidade de trabalho e escola a todos. No que se refere a escola, é sabido que a aprovação ou mudança de série do estudante, disciplina, assim como não envolver em nenhum conflito, é fundamental para que possa usufruir de forma ampla desse benefício, e assim diminuir seu tempo no cárcere.

Por fim, cabe destacar as particularidades de um universo feminino, no que diz respeito à saúde, beleza, higiene, maternidade, trabalho, escolaridade, em que estes foram pensados historicamente sobre a perspectiva masculina e que nesse século o descuido ainda é muito evidente. Políticas voltadas para a reinserção social, escolaridade, emprego e renda, bem como cuidado com os filhos menores, ainda são bastante frágeis. Dentro ou fora do cárcere não existem oportunidades de trabalho remunerado para todas, tampouco oportunidades de estudo. Entrar para o crime, principalmente o tráfico de drogas, nos aponta uma busca de renda, e sair dessa rede indica caminhos muito difíceis, em que laços de parentesco, manutenção de renda, dificuldade de se inserir no mercado formal de trabalho, dependência financeira, ligações afetivas anteriores ao aprisionamento, medo, submissão aos companheiros ou 
familiares, enredam uma trama muito complexa. As mulheres encarceradas que almejam se distanciar do crime e reorganizar sua trajetória de vida após o cárcere tem a sua frente uma realidade muito complexa, pois além de trazerem as marcas do presídio, tem uma escolaridade e formação para o trabalho precárias. Somam-se a estas a violência daqueles que possuem laços de afetividade, exigência de cuidar e alimentar os filhos, retorno para locais em que as políticas de moradia, emprego, saúde, segurança e direitos individuais e coletivos ainda são precários. Assim, sair do cárcere não representa sair do crime, mas estar muito próximo dele, cabendo a cada uma delas fazer seu percurso de ressocialização.

\section{Referências}

BEATO, Cláudio. Crimes e Cidades. Belo Horizonte: Editora UFMG, 2012.

BRASIL. Ministério da Justiça/Departamento Penitenciário Nacional. Relatório Levantamento Nacional de Informações Penitenciárias INFOPEN - junho de 2014.

BRASIL. Lei 7.210/84 de Execução Penal. Brasília, DF: Senado Federal, 1984.

BRASIL. Lei 12.433 de 2011. Altera a Lei $n^{0}$ 7.210, de 11 de julho de 1984 (Lei de Execução Penal). Brasília, DF: Senado Federal, 2011.

CAMPOS, Alzira L. de Arruda.; TRINDADE, L. Sálvia.; COELHO, Lúcia M. Sálvia. Mulheres Criminosas na Abordagem Interdisciplinar. Pesquisa em Debate. Edição 9, v. 5, n. 2, jul - dez 2008.

CANÊDO, Carlos.; FONSECA, David (Orgs). Ambivalência, Contradição e Volatilidade no Sistema Penal. Belo Horizonte: Editora UFMG, 2012.

FOUCAULT, Michel. Segurança, penalidade, prisão. Org. Manoel de B. da Motta; trad. Vera L. A Ribeiro. Rio de Janeiro: Forense Universitária, 2012. Ditos \& escritos VIII.

FOUCAULT, Michel. Vigiar e Punir. 14 ed. Petrópolis: Vozes, 1996.

LEMOS BRITTO, José Gabriel de. Os Systemas Penitenciários do Brasil. Rio de Janeiro: Imprensa Nacional, 1924.

SILVA, Vanusa Santos. Fios de tragédia: o feminino que mata. In: Simpósio Nacional de História, XXVII, 2013. Anais do Simpósio Nacional de História, Rio G. do Norte: ANPUH-Brasil, julho, 2013. 


\section{Como referenciar este artigo}

SILVA, Maria Cristina.; EITERER. Carmem Lucia. Mulheres no cárcere e educação de adultos. Revista Ibero-Americana de Estudos em Educação, Araraquara/SP, v. 12, n. 2, p. 793-814, 2017. Disponível em: <https://dx.doi.org/10.21723/riaee.v11.esp2.p861880>. E-ISSN: 1982-5587.

Recebido em: 18/02/2016

Aprovação final em: 29/03/2017 